\title{
DECOLORIZATION AND PHYSICO CHEMICAL ANALYSIS OF TEXTILE AZO DYE BY BACLUS
}

\author{
Arul Jayan M. ${ }^{1}$, Revathi Maragatham. $\mathrm{N}^{2}$, Saravanan . $\mathrm{J}^{3}$ \\ 1,2,3 Department of Chemical Engineering, Periyar Maniammai University, Thanjavur, India \\ Email: ${ }^{1}$ shajivenoth@gmail.com
}

\begin{abstract}
Water pollution control is at present one of the major areas of scientific activity. The textile wastewaters are characterized by extreme fluctuations in many parameters such as chemical oxygen demand (COD), biochemical oxygen demand (BOD), pH, colour and salinity. Biotreatment offers a cheaper and environmentally friendlier alternative for colour removal in textile effluents. The ubiquitous nature of bacteria makes them invaluable tools in effluent biotreatment. Potential decolourization and COD removal of the simulated effluent by each isolate were investigated. The gram staining test showed the isolate to be non-motile, gram positive, spore forming, rod-shaped bacteria. Biochemical characterization of the isolate revealed it to be negative for Indole, Methyl Red test. The potential strain was phylogenetically identified as Bacillus. Only effluent-adapted isolates of Bacillus species have relatively high $\mathrm{COD}$ removal activities while all the non-adapted isolates have high $\mathrm{COD}$ removal capabilities. This study discovered effluent adapted strains of Bacillus with potentials for colour removal and strains of Bacillus with potential use for COD removal. The results suggest that the non-adapted adapted isolates. Reports however indicate that though several microorganisms may seem to have a potential for dye degradation, very few strains can withstand the conditions of dyeing effluents thus the effluent-adapted strains may be better candidates for potential bioremediative uses.
\end{abstract}

Keywords: $\mathrm{COD}, \mathrm{BOD}$, Bacillus, Methyl red test

\section{INTRODUCTION}

Water pollution control is at present one of the major areas of scientific activity. Textile industries are large industrial consumers of waters as well as producers of wastewaters. With the increased demand for textile products, the textile industry and its wastewaters have been increasing proportionally, making it one of the main sources of severe pollution problems worldwide. The diversity in composition of chemical reagents used in textile industries contributes to much of the water pollution. The reagents range from inorganic compounds to polymers and organic products. Waste water generated by different production steps of a textile mill have high $\mathrm{pH}$, temperature, detergents, oil, suspended and dissolved solids, dispersants, leveling agents, toxic and non-biodegradable matter, color and alkalinity. Important pollutants in textile effluent are mainly recalcitrant organics, color, toxicants and surfactants, chlorinated compounds (AOX). The textile wastewaters are characterized by extreme fluctuations in many parameters such as chemical oxygen demand (COD), biochemical oxygen demand (BOD), $\mathrm{pH}$, colour and salinity. The process of adding colour to the fibres is known as dyeing which normally requires large volumes of water not only in the dye bath, but also during the rinsing step? The process of dyeing involves the use of different chemicals like salts, metals, surfactants, organic processing assistants, sulphide and formaldehyde. There are more than 8,000 chemical products associated with the dyeing process and over 100,000 commercially available dyes exist with over $7 \times 105$ metric tons of dyestuff produced annually (chagas \& duarrnt, 2001).

Approximately a half of all known dyes are azo dyes, making them the largest group of synthetic colorants. Azo dyes consist of a diazotized amine coupled to an amine or phenol. Atleast 3000 different varieties of azo dyes are extensively used in the textile, paper, food, cosmetics and pharmaceutical industries (yatome etal., 1981). Azo dyes are characterized by the presence of one or more azo groups (R1-N=N-R2) which are responsible for their colorations and when such a bond is broken (degraded) the compound loses its color. A related topic having received considerable interest is the presence of color in effluents associated with production of dyes. Biotreatment offers a cheaper and environmentally friendlier alternative for colour removal in textile effluents. The ubiquitous nature of bacteria makes them invaluable tools in effluent 
biotreatment. The chemical nature of dyes varies, but azo dyes are the most widely used. The oxidative decolourizations of dyes of several classes have been reported and azo dyes were found to be the most recalcitrant compounds. (Maeir et al., 2004). The decolourization of azo dyes has been found to be effective under anaerobic conditions However, the anaerobic degradation yields aromatic amines which are mutagenic and toxic to humans and cannot be metabolized further under the conditions which generated them (Chung and Stevens, 1993; Do et al., 2002). In activated sludge treatments of dye effluents, reactive azo dyes and aromatic amino derivatives are a non-biodegradable class of compounds which can even inhibit activated sludge organism (Maeir et al., 2004). It is thus important to explore the possibilities of isolating efficient aerobic degraders for use in decolourization and biotreatment of textile effluents. In a bid to exploit the biodegradation abilities of our indigenous microbial flora for premeditative purposes, we isolated and screened organisms for the ability to decolourize and/or reduce the COD of textile effluents. The isolates were also screened for plasmids in order to determine the contribution of extra-chromosomal genetic factors to the degradative ability. The study is aimed at discovering isolates with the potential for use in biological treatment of textile effluents.con

\section{MATERIALS AND METHODS}

\section{(A) Sampling and analysis of effluent}

Coimbatore is one of the most industrialized cities in Tamil Nadu, India. It is known as the textile capital of South India or the Manchester of the South India (Lat. $11^{\circ} 00^{\prime} \mathrm{N}$, Long. $77^{\circ} 00^{\prime} \mathrm{E}$ ) and was chosen for effluent sample collection. The Effluent sample was collected from the middle point of the area. Standard procedures (Spot and Grab) were followed during sampling. The Temperature and $\mathrm{pH}$ were determined at the sampling site. The $\mathrm{pH}$ was determined by using pH meter (Hanna digital pH meter, model-671-p) and temperature with laboratory thermometer. The sample was transported to laboratory at $4^{\circ} \mathrm{C}$ as in accordance with the standard methods. The physicochemical parameters such as (Colour, Electrical Conductivity (EC), Biological Oxidation Demand (BOD) Chemical Oxygen Demand (COD), Total Suspended Solids (TSS), Total Dissolved Solids (TDS), heavy metal ions) were determined as soon as the sample was brought to the laboratory and are reported in Table 1

\section{(B) Materials}

All chemicals used are of analytical grade. The reactive dyes used: Orange P3R, Yellow P3R, Blue H5R, Violet P3R, Brown P5R, Black V3R, Orange P2R were kindly donated by one of the textile companies whose effluent was used as a source of effluent adapted bacteria.

Table 1. Physicochemical characterization of the textile effluent

\begin{tabular}{|c|l|l|l|}
\hline S.No & \multicolumn{1}{|c|}{ Parameter } & \multicolumn{1}{|c|}{ Units } & \multicolumn{1}{|c|}{ Effluent } \\
\hline 1. & Colour & - & Black \\
\hline 2. & Smell & - & Plungent \\
\hline 3. & Temperature & ${ }^{\circ} \mathrm{C}$ & 40 \\
\hline 4. & $\mathrm{PH}$ & - & 7.51 \\
\hline 5. & $\mathrm{EC}$ & & 9565 \\
\hline 6. & $\mathrm{TSS}$ & $\mathrm{Mhos} / \mathrm{cm}^{\prime}$ & 1750 \\
\hline 7. & $\mathrm{TDS}$ & $\mathrm{Mg} \mathrm{I}^{-1}$ & 5875 \\
\hline 8. & $\mathrm{Cl}-$ & $\mathrm{Mg} \mathrm{I}^{-1}$ & 2013 \\
\hline 9. & $\mathrm{Ca}$ & $\mathrm{Mg} \mathrm{I}^{-1}$ & 1500 \\
\hline 10. & $\mathrm{Mg}$ & $\mathrm{Mg} \mathrm{I}^{-1}$ & 889 \\
\hline
\end{tabular}

\section{(C) Sterilization techniques}

All glass wares were washed with detergent, rinsed thoroughly with distilled water and oven sterilized at $80^{\circ} \mathrm{C}$ for $2.5 \mathrm{~h}$. All polypropylene tubes and tips used as well as media and solutions prepared were sterilized by autoclaving at $121^{\circ} \mathrm{C}$ for $15-25 \mathrm{~min}$. Inoculations were done with flame sterilized loops and all experiments were performed wearing sterile disposable hand gloves.

\section{(D) Sources of organisms}

Textile effluent-adapted bacteria were isolated from effluent samples collected from the discharge and drainage pipes of three textile industries. The textile effluent non-adapted bacteria were isolated from soil samples taken from a municipal landfill. All isolations 
were done on nutrient agar using enrichment culture techniques and the organisms identified to the generic level using the Cowan and Steel Scheme (1993).

\section{(E) Preparation of simulated effluent}

A stock dye solution was prepared with $80 \mathrm{mg}$ of each of the seven dyes used per L; giving a concentration of $5.6 \mathrm{~g}$ dyes mix/L. To prepare the simulated effluent the stock solution was supplemented with modified minimal medium (Mills et al., 1978) to get a final conc- Olukanni et al. 1981 entration of 56 $\mathrm{mg} / \mathrm{L}$.

\section{(F) Determination of biodegradation activity}

Potential decolourization and COD removal of the simulated effluent by each isolate were investigated. Into $20 \mathrm{ml}$ simulated effluent $2 \times 105 \mathrm{cfu}$ of the isolate was added in transparent bottles $(200 \mathrm{mg} / \mathrm{L}$ starch and $250 \mathrm{mg} / \mathrm{L}$ yeast extract were added as cosubstrates) and cocked with sterile cotton wool. After 14 days decolourization and COD removal were measured. Decolourization was determined by measuring the absorbance of the simulated effluent at the effluent pre-determined I $\max (485 \mathrm{~nm})$ and the absorbance of the treated simulated effluent. The $\%$ decolourization was calculated as $[(\mathrm{Ao}-\mathrm{At}) / \mathrm{Ao}] \times 100 \%$, Where is absorbance of the simulated effluent and At the absorbance of the treated simulated effluent 14 days post microbial innoculation. The COD of the simulated and treated effluents were determined by a standard spectroscopic method (APHA, 1980).

\section{(G) Plasmid screening}

The isolates were screened for plasmids using the plasmid isolation technique described by Kado and Liu (1981) followed by electrophoresis on $0.8 \%$ agarose gels. The gels were stained with ethidium bromide and viewed on a UV transilluminator.

\section{RESULTS}

\section{(A) Isolation and identification}

The study was started by screening for potential textile Azo dye decolorizing bacteria isolated from the textile industry effluent. Colonies surrounded by a nearly decolorized zone were isolated and then tested for dye removal capability using submerged culture. Strains isolated from the white colonies were inoculated in $100 \mathrm{ml}$.of Nutrient broth in a $250 \mathrm{ml}$.conical flask and incubated at $35^{\circ} \mathrm{C}$ under static conditions. One strain exhibiting highest decolorizing activity was chosen for further studies. The gram staining test showed the isolate to be non-motile, gram positive, spore forming, rod-shaped bacteria. Biochemical characterization of the isolate revealed it to be negative for Indole, Methyl Red test. The potential strain was phylogenetically identified as Bacillus. The results are compiled in Table 2

\section{(B) Source and identity of isolates}

A total of 24 isolates were obtained; eighteen organisms belonging to the genera, Bacillus, were isolated from the textile effluents (effluent-adapted bacteria) while six isolates belonging to the genus Bacillus were isolated from the landfill site (effluent nonadapted isolates).

\section{(C) Biodegradation}

The majority of the effluent adapted isolated showed colour-removing activities between 40.74 and $47.73 \%$. For the effluent adapted bacteria, isolates of Bacillus may be potentially useful in decolourization processes, whereas the six nonadapted Bacillus isolates seem to be potentially useful. The non-adapted isolates had decolourization activities of between 40.25 and $46.63 \%$. This was similar to that of the majority of the effluent adapted organisms. The non-adapted Bacillus isolates had a relatively higher mean \% COD removal when compared to the adapted microbes of the same species or to the mean \% COD removal for

Table 2 The sources and identity of the isolates

\begin{tabular}{|c|c|c|c|c|c|c|c|c|c|c|}
\hline Lab \# & $\begin{array}{c}\text { Grams } \\
\text { reaction }\end{array}$ & Shape & $\begin{array}{c}\text { Aerobic } \\
\text { growth }\end{array}$ & $\begin{array}{c}\text { MacConke } \\
\text { y growth }\end{array}$ & $\begin{array}{c}\text { Lactose } \\
\text { fermentati } \\
\text { on }\end{array}$ & Endospore & Motility & Catalase & Oxidase & $\begin{array}{c}\text { Identity } \\
\text { (Genus) }\end{array}$ \\
\hline $\mathrm{T} 1$ & + & Rod & + & + & + & + & + & + & - & Bacillus \\
\hline
\end{tabular}


all the adapted isolates. Only effluent-adapted isolates of Bacillus species have relatively high COD removal activities, while all the non-adapted isolates have high COD removal capabilities.

\section{(D) Plasmid screening}

Plasmids were not detected in any of the isolates from the effluent adapted or non- adapted sources.

\section{CONCLUSION}

The textile industries are multi-chemical utilizing concerns of which dyes of various types are of importance. During the dyeing process a substantial amount of dyes and other chemicals are lost in the waste water. Estimates put the dye losses at between 10-15\% (Vaidya and Datye, 1982). Though not generally toxic to the environment, dyes colour water bodies and may hinder light penetration thereby affecting aquatic life and limiting the utilization (Ajayi and Osibanjo, 1980; Goncalves et al., 2000). It has been reported that a typical textile effluent contains a dye mass concentration of $10-50 \mathrm{mg} / \mathrm{L}$ (Clarke and Anliker, 1980). However, the human eye can detect levels as low as $0.005 \mathrm{mg} / \mathrm{L}$ of reactive dyes in a clear river (Pierce, 1994). In our study a simulated effluent with a dye mass of $56 \mathrm{mg} / \mathrm{L}$ was used. The simulated effluent was supplemented with starch and yeast extract to provide nutrients for biomass maintenance and to enhance biodegration (Do et al., 2002, Padmavathy et al., 2003). The Biodegradation of simulated textile effluent under aerobic condition and the mean biodegradative activities of the isolated genera are shown in Tables 3 and 4.

This study discovered effluent adapted strains of Bacillus with potentials for colour removal and strains of Bacillus with potential use for COD removal. The municipal landfill site soils yielded strains of bacillus with potentials for use in colour and COD removal.

Table 3 Biodegradation of simulated textile effluent under aerobic condition

\begin{tabular}{|c|c|c|c|c|c|}
\hline \multirow[b]{2}{*}{ Lab \# } & \multirow[b]{2}{*}{$\begin{array}{l}\text { Identity } \\
\text { (Genus) }\end{array}$} & \multicolumn{3}{|c|}{ COD mg/l } & \multirow{2}{*}{$\begin{array}{c}\% \\
\text { Decolour } \\
\text { ization }\end{array}$} \\
\hline & & Initial & Final & $\begin{array}{c}\% \\
\text { Removal }\end{array}$ & \\
\hline T1 & Bacillus & 1038 & 788 & 24.08 & 47.24 \\
\hline
\end{tabular}

Table 4 Mean biodegradative activities of the isolated genera.

\begin{tabular}{|l|c|c|c|}
\hline Genus & N & $\begin{array}{c}\% \text { COD } \\
\text { removal \# }\end{array}$ & $\begin{array}{c}\% \\
\text { Decolourizati } \\
\text { on\# }\end{array}$ \\
\hline Bacillus \\
\hline $\begin{array}{c}\text { T - Strains } \\
\text { N - Strains }\end{array}$ & 6 & $55.89 \pm 1.70$ & $43.95 \pm 0.91$ \\
\hline
\end{tabular}

This may be due to the significant exposureof these organisms to a myriad of chemicals and materials some of which contain dyes which are deposited in the landfill which may cause a release of dyes to the soil. The results suggest that the non-adapted bacillus species have a relatively higher potential use than the textile effluent adapted isolates. Reports however indicate that though several microorganisms may seem to have a potential for dye degradation, very few strains can withstand the conditions of dyeing effluents (Maeir et al., 2004); thus the effluent-adapted strains may be better candidates for potential bioremediative uses. However, our result does not indicate the involvement of extra-chromosomal genes in the degradative activity of the isolates. In conclusion, as a preliminary step in the development of textile effluent biotreatment processes involving indigenous microbes, we have discovered textile effluent adapted strains of Bacillus, and effluent non-adapted Bacillus species with potential use in effluent treatment.

\section{REFERENCES}

[1] Ajayi SO, Osibanjo O (1980). The state of environment in Nig. Pollution studies of textile industries in Nig. Monogra. 1:76-86.

[2] APHA (1980). American Public Health Association standard methods for the examination of water and wastewater. R.R Donnelley and sons. 15th ed.

[3] Chung KT, Stevens SEJ (1993). Degradation of azo dyes by environmental microorganisms and helminthes. Environ. Toxico. Chem. 12:2121-2132.

[4] Clarke EA, Anliker R (1980). Organic dyes and pigments. Handbook of Environmental Chemistry. Springer Verlag.

[5] Cooper P (1995). Colour in dyehouse effluent. Society of dyers and colourists, Bradford

[6] Cowan, Steel's (1993). manual for the identification of Medical Bacteria, 3rd Edition. Cambridge University Press. 
[7] Do T, Shen J, Cawood G, Jeckins R (2002). Biotreatment of textile effluent using Pseudomonas spp. Immobilized on polymer supports. In: Advances in biotreatment for textile processing. Hardin, I.R; Akin

[8] D.E \& Wilson J.S (Eds). University of Georgia Press.Goncalves IMC, Gomes A, Bras R, Ferra MIA, Amorin MTP, Porter RS(2000). Biological treatment of effluent containing textile dyes. JSDC. 116:393-397.

[9] Kado Cl, Liu ST (1981). Rapid procedure for detection and isolation oflarge and small plasmids. J. bacterial 145, pp. 1365 - 1373.

[10] Maier J, Kandelbauer A, Erlacher A, Cavaco - Paulo A, Gubits GM (2004). A new alkali - thermostable azoreductase from bacillus sp. Strain SF. Appl. Environ. Microbial 70: 837 - 844.

[11] Mills AL, Breuil C, Colwell RR (1978). Enumeration of petroleumdegradingmarine and estuarine microorganisms by the most Probable number method. Can. J. Microbial. 24: 552-557. Olayinka KO, Alo BI (2004).

[12] Studies on industrial pollution in Nig. Theeffect of Textile effluent on the quality of ground waters in some parts Lagos. Nig. J. Health. Biomed. Sci. Padmavanthy S, Sandhyan S, Swaminathan K, Subrahmanyarn YV, Chakrabarti T, Kaul SN (2003).

[13] Aerobic decolourisation of reactive azo dyes in presence of cosubstrates. Chem. Biochem. Eng. Q. 17 (2) pp. 147-151. Pierce J (1994).

[14] Colour in textile effluents - the origins of the problem.JSDC 110. 131-133.

Vaidya AA, Datye KV (1982).
[15] Environmental pollution during chemical processing of synthetic fibers. Colourage 14: 3-10 Asia IO, Oladoja NA, Bamuza-pemu EE. [2006]

[16] Treatment of Textile Sludge using naerobic technology. African Journal of Biotechnology 5 (18): 1678-1683.

[17] Andre dos BS, Francisco JC, Jules van BL. [2007] Review paper on current echnologies for decolourisation of textile wastewaters: Perspectives for anaerobic Biotechnology. Bioresource Technology 98: 2369-2385.

[18] Mishra G, Tripathy M. [1993] A critical review of the treatments for decolourisation of textile effluent.Colourage 40: 35--38.

[19] Kumar P, Prasad B, Mishra IM, Chand S.[ 2007] Haz Mater 149: 26-34.

[20] Talarposhti AM, Donnelly T, Anderson GK. [2001] Colour removal from a simulated dye wastewater using a two-phase anerobic packed bed reactor. Water Res 35: 425-432.

[21] Zollinger H. [1987] Colour Chemistry-Synthesis, Properties and Application of Organic dyes and pigments. VCH publishers, New York, p. 92-100.

[22] Brown MA, De Uito SC. [1993] Predicting azo dye toxicity. Crit Rev Environ Sci Technol 23: 249-324.

[23] Chagas EP, Durrant LR. [2001] Decolorization of azo dyes by Phanerochaete chrysosporium and Pleurotus sajorcaju. Enzyme Microb Technol 29: 473-477.

[24] Yatome C, Ogawa T, Koga D, Idaka E. [1981] Biodegradability of azo and triphenylmethanes dyes by Pseudomonas pseudomallei 13NA. Journal of Society of Dyers and Colorists 97: 166-169. 